\title{
Strategi Bisnis Startup Social Enterprise Wahyoo Dalam Menghadapi Situasi Pandemi Covid-19
}

\author{
Siti Qona'ah \\ Universitas Bina Sarana Informatika \\ Email : $\underline{\text { Siti.sqa@bsi.ac.id }}$
}

Cara Sitasi: Siti Q (2021), Strategi Bisnis Startup Social Enterprise Wahyoo Dalam Menghadapi Situasi Pandemi Covid-19 (2021) 21 (1), 1- 9 Retrieved from https://doi.org/10.31294/jc.v19i2

\begin{abstract}
Abstrak - Wahyoo's entrepreneurial startup is a technology company established in 2017 and provides added value that is beneficial to stalls in Indonesia. Wahyoo experienced the Covid-19 Pandemic crisis so that Wahyoo's income decreased by 50\%. Warung Tegal (warteg) is a Micro, Small and Medium Enterprise that is affected by a policy issued by the government to break the chain of covid distribution, namely regional quarantine, large-scale social restrictions (PSBB) and lockdown. For that we need digital technology such as social entrepreneur startup Wahyoo which in carrying out its business strategy can face the Covid-19 pandemic. The purpose of this research is to describe what Business Strategy steps carried out by Wahyoo's social enterprise startups in the face of the COVID-19 pandemic situation. In this study, researchers used a qualitative approach and case studies. With the observation and documentation research method as a research method that illustrates that the Wahyoo Social Enterprise Startup Business Strategy steps that have been implemented through \# Rantang Hati, Warteg New normal and opening new units can deal with the COVID-19 Pandemic Situation
\end{abstract}

Key words: Business Strategy, Startup, Pandemic

\section{PENDAHULUAN}

Sejak Desember 2019, seluruh negara mengalami wabah virus corona yang mengakibatkan kematian pada penderitanya dan penyakit ini menular secara cepat. COVID-19 (Coronavirus Disease-19) (Https://www.who.int/ 2020) adalah penyakit menular yang disebabkan oleh evere acute respiratory syndrome coronavirus 2 (SARS-CoV-2), yang sama dengan penyebab SARS pada tahun 2003. Meski tergolong dalam satu keluarga besar virus, namun berbeda jenis virus, dan penyebarannya lebih luas dan cepat dibanding virus SARS. Sejak Desember tahun 2019, negara-negara di dunia mengalami pandemi penyakit menular ini, sehingga Badan Kesehatan Dunia atau World Health Organization (WHO) pada tanggal 30 Januari 2020 mendeklarasikan sebagai Public Health Emergency of International Concern (PHEIC) atau Kedaruratan Kesehatan Masyarakat yang Meresahkan Dunia.(Https://www.who.int/ 2020)

Berbagai upaya Pemerintah untuk memberikan solusi untuk menekan angka penyebaran virus yang terjadi dengan cepat yaitu dengan menghentikan penularan virus yaitu melalui mengurangi interaksi atau kontak langsung antar masyarakat. Tiga istilah yang digunakan yaitu karantina wilayah, Pembatasan Sosial Berskala Besar (PSBB) dan lockdown.
Usaha Mikro Kecil Menengah merupakan salah satu yang terkena dampak karena adanya kebijakan PSPB, seperti yang disampaikan oleh Kementerian Koperasi dan UKM mencatat ada sebanyak 67.051 pelaku Usaha Mikro Kecil dan Menengah (UMKM) terdampak karena adanya pandemi Covid-19 di Indonesia. Data itu berdasarkan laporan dari dinas di provinsi, kabupaten dan kota per tanggal 20 Juni 2020.(Prayoga 2020)

Lebih lanjut Destry menjelaskan, "penyebab utama UMKM terkena dampak dari pandemi Covid-19 lantaran penjualan menurun, sulitnya bahan baku, distribusi terhambat, permodalan dan produksi terhambat. Dia menilai permasalahan itu muncul karena kebijakan dari pembatasan sosial berskala besar (PSBB)".(Prayoga 2020)

Kamar Dagang dan Industri Indonesia (Kadin) mengungkapkan, "bila rumah makan warung tegal (Warteg) merupakan salah satu elemen sektor riil yang tergolong Usaha Mikro Kecil, dan Menengah (UMKM)". (Lestarini 2020)

\footnotetext{
"Warteg tergolong UMKM, sudah selayaknya mendapatkan dukungan dari pemerintah untuk dapat terus tumbuh," kata Wakil Ketua Komite Tetap Pemberdayaan Daerah Kadin Iqbal Farabi. (Lestarini 2020)
} 
Kebijakan lockdown juga memberikan dampak pada Warteg. Ketua Komunitas Warteg Nusantara (Kowantara) Mukroni, menyatakan "Pengusaha warung tegal (warteg) mengalami penurunan omzet yang cukup dalam terkena dampak virus corona. Omzet mereka turun sekitar 50\% , karena corona membuat dagangan mereka sepi pembeli Drastis, hampir 50\%," (Afriyadi 2020)

Mukroni menjelaskan, "jumlah pengusaha warteg di Jakarta sampai 40.000 orang. Saat ini, pengusaha warteg bingung karena Pemerintah Kota Tegal menerapkan kebijakan lockdown karena sulit kembali ke kampung halaman namun di sisi lain untuk bertahan hidup di Jakarta biayanya tak sedikit". (Afriyadi 2020)

Untuk mempertahankan usaha UMKM seperti Warteg diperlukan teknologi digital seperti startup teknologi yang dapat menghasilkan multiplier effect seperti pengelolaannya lebih mudah dan praktis

Setiap tahun bahkan setiap bulan banyak startup baru bermunculan. Sekarang ini terdapat setidaknya lebih dari 1500 startup lokal yang ada di Indonesia, dikutip dari Daily Social. Potensi pengguna internet di Indonesia yang semakin meningkat dari tahun ke tahun juga menjadi katalis mendirikan sebuah startup. (Rizka 2019)

Dave McClure, founding partner dari 500 Startup menjelaskan bahwa, "sebuah Startup adalah rintisan usaha yang masih belum jelas akan pruduk, siapa customernya, dan bagaimana model bisnisnya." (Rizka 2019)

Dalam laporan yang bertajuk Mapping \& Database Startup Indonesia 2018 dari Indonesia Digital Creative Industry Society jumlah perusahaan rintisan teknologi di Indonesia mencapai 992 startup. Dari jumlah tersebut, sebanyak 522 startup atau lebih dari separuh berada di wilayah Jabodetabek. Wilayah terbanyak kedua tempat tumbuhnya startup adalah Sumatera, yakni mencapai 115 startup dan Jawa Timur terdapat 113 startup di urutan kedua. (https://databoks.katadata.co.id/ 2019)

Diantara beragam model startup yang terus bermunculan di Indonesia, ada beberapa startup yang tujuan awal pendiriannya tidak hanya sekedar mencari keuntungan semata, namun juga mempunya misi sosial tertentu (social entrepreneurship)

Startup social enterprise Wahyoo berdiri pada Mei 2017. Wahyoo merupakan platform jasa bagi pengusaha warung makan yang menyediakan berbagai layanan, seperti penjualan pulsa, edukasi usaha katering, program asistensi bisnis, hingga standardisasi kebersihan tempat usaha.

CEO AR \& Co Wahyoo Peter Shearer menyatakan, "Bisnis warung makan saat ini dijalankan dengan sangat sederhana dan belum memanfaatkan teknologi karena itu Wahyoo saya dirikan untuk mengoptimalkan bisnis ini,"

Mengusung tagline \#BeraniBermimpi, Wahyoo hadir dalam platform aplikasi digital dan situs website www.wahyoo.com. Platform ini mengemban misi membantu meningkatkan usaha pemilik warung makan agar lebih relevan dengan kemajuan zaman. Dengan memanfaatkan teknologi digital dalam pengelolaannya, image warung makan tradisional (semacam Warung Tegal atau Warteg) akan terangkat menjadi warung makan modern.

Lebih lanjut Peter menyatakan, "Dilihat dari jumlah pengunjung, setiap warung makan rata-rata menggaet 100 orang pengunjung setiap hari. Dengan total warung yang ada, maka sedikitnya ada 300.000 orang berhimpun di warung makan. Hal ini merupakan potensi besar untuk mengembangkan warung menjadi one stop shopping. "Fungsi ini yang akan kami kedepankan. Jadi warung ini bukan hanya sebagai tempat makan, melainkan juga menjadi agen pulsa, tempat branding perusahaan, dan masih banyak lagi."

Peter menyatakan bahwa. "Dari total sekitar 3000-an warung makan yang ada di Jakarta, baru 315 warung makan yang terdaftar. Upaya edukasi kepada para pemilik warung pun dilakukan bersama timnya dengan cara mendatangi satu per satu warung makan untuk menjelaskan kemudahan dan benefit yang didapat apabila bergabung dengan Wahyoo. "Tahun ini kami menargetkan 2.000 warung makan terdaftar dan bergabung di Wahyoo,".(Setiawan 2018)

Di Masa Pandemic Covid-19 dengan adanya kebijakan Pembatasan Sosial Berskala Besar, pendapatan Wahyoo menurun 50\%. Menurut Daniel, pada acara 'APPRIConnect for Business yang digelar APPRI menyatakan "Bahkan, dari 13.500 mitra warung makan di Jakarta, Depok, Tangerang, dan Bekasi yang telah bergabung dengan Wahyoo, beberapa di antaranya harus tutup. Terutama, mitra warung makan yang berada di kawasan kampus dan perkantoran," (Wulandari 2020)

Untuk mengatasi masalah tersebut maka diperlukan langkah- langkah strategi bisnis dalam menghadapi situasi pandemic covid-19, maka penulis ingin mengetahui bagaimana Startegi Bisnis Startup Social Enterprise Wahyoo dalam menghadapi situasi pandemi COVID-19.

Tujuan dari penelitian ini adalah untuk mendeskripsikan langkah Startegi Bisnis apa saja yang dilaksanakan starup social enterprise wahyoo dalam menghadapi situasi pandemi COVID-19.

Teori Yang digunakan dalam penelitian ini yaitu : 


\section{Strategi Bisnis}

Strategi menurut Potler adalah alat untuk mencapai keunggulan bersaing. Merujuk pada beberapa pandangan tentang definisi strategi yang diutarakan oleh para ahli. Maka, istilah strategi bermakna suatu kesatuan rencana yang bersifat menyeluruh, komprehensif, dan terpadu pada arahan guna mencapai tujuan yang diinginkan. (Susanto 2005).

Strategi bisnis adalah "upaya perusahaan dalam mengambil suatu kebijakan dan pedoman yang mempunyai komitmen dan tindakan yang terintegrasi. Hal tersebut dirancang untuk membangun keunggulan dalam persaingan bisnis untuk memenuhi dan mencapai tujuan bisnis.”(https://mastahbisnis.com/ 2020)

3 jenis Strategi bisnis yaitu :

1. Pertumbuhan, Strategi pertumbuhan adalah pada saat suatu organisasi atau perusahaan memperluas jumlah pasar yang dilayani atau produk yang ditawarkan, baik dengan melalui bisnis nya saat ini atau dengan membuka bisnis baru. Dengan menggunakan strategi ini suatu organisasi bisa meningkatkan jumlah pendapatannya, jumlah karyawan, atau pun pangsa pasarnya.

2. Stabilitas. Strategi stabilitas adalah suatu strategi organisasi yang dimana organisasi terus melakukan apa yang sedang dilakukannya sekarang. Misalnya seperti terus melayani pelanggan atau konsumen yang sama dengan cara menawarkan produk atau layanan yang sama, mempertahankan pangsa pasar yang ada, dan mempertahankan operasi bisnis saat ini. Dalam hal ini organisasi tidak mengalami pertumbuhan dan tidak juga mengalami kemunduran.

3. Pembaharuan, Pada saat sudah organisasi atau perusahaan sedang mengalami masalah, maka organisasi tersebut harus melakukan sesuatu. Para manajer harus mengembangkan suatu strategi, yang disebut dengan strategi pembaruan, yang menangani penurunan kinerja organisasi. (https://mastahbisnis.com/ 2020)

\section{Startup}

Startup adalah, "perusahaan rintisan atau perusahaan baru yang sedang dikembangkan.” (Marikxon 2020)

Startup adalah "sesuatu yang merujuk pada perusahaan yang belum lama beroperasi. Perusahaanperusahaan ini sebagian besar merupakan perusahaan yang baru didirikan dan berada dalam fase pengembangan dan penelitian untuk menemukan pasar yang tepat. Jadi kalau dirangkum secara singkat startup adalah perusahaan baru yang sedang dikembangkan atau belum lama beroperasi. Oleh karena itu startup sering disebut sebagai perusahaan rintisan”. (Liputan6.com 2019)

Startup adalah "sesuatu bisnis yang baru saja berdiri dan berkembang dengan didukung oleh layanan digital dan masih butuh banyak pendanaan untuk beroperasi dengan kelompok kerja yang minimalis." Startup adalah sebuah kata yang berasal dari Bahasa Inggris yakni start-up dan merujuk pada pengertian semua perusahaan yang belum lama beroperasi atau perusahaan rintisan. Startup menjadi populer secara internasional pada masa bubble dot-com sekitar tahun 1998 hingga 2000. Banyak perusahaan dot-com didirikan secara bersamaan pada periode tersebut, dikarenakan saat itu sedang gencarnya perusahaan perintis untuk membuka website pribadi demi memulai bisnisnya.(Liputan6.com 2019)

Ciri-ciri dari perusahaan startup, diantaranya sebagai berikut:

1. Perusahaan baru berdiri kurang dari 3 (tiga) tahun.

2. Jumlah karyawan yang dimiliki kurang dari 20 orang.

3. Penghasilan pertahunnya masih kurang dari $\$ 100.000$.

4. Tengah dalam fase perkembangan.

5. Biasanya berjalan di dunia teknologi dan web (online).

6. Produk yang dihasilkan berupa aplikasi digital.

7. Umumnya berjalan lewat website.(Https://pendidikan.co.id 2020)

Terdapat 3 kelompok startup yang banyak saat ini berkembang di Indonesia, diantaranya sebagai berikut:

1. Startup aplikasi pendidikan

2. Startup pencipta game

3. Startup perdagangan seperti e-commerce dan informasi.(Https://pendidikan.co.id 2020)

\section{Social Enterprise}

Social enterprise atau wirausaha sosial adalah sebuah organisasi atau perusahaan yang menggunakan strategi komersial untuk meningkatkan kesejahteraan finansial, sosial, dan lingkungan-untuk memaksimalkan profit sekaligus dampak baik bagi setiap elemen yang terlibat di dalam usahanya.(Https://www.dbs.com/ 2018)

Pada dasarnya, ada 5 elemen yang perlu hadir dalam sebuah social enterprise.

1. Misi atau dampak sosial

2. Pemberdayaan 
3. Prinsip bisnis yang etis

4. Reinvestasi dana untuk misi sosial

5. Kesinambungan(Https://www.dbs.com/ 2018)

\section{Pandemi Covid-19}

Pandemi merupakan "wabah penyakit yang terjadi pada geografis yang luas atau menyebar secara global. Menurut WHO, pandemi tidak ada hubungannya dengan tingkat keparahan penyakit, jumlah korban atau infeksi, namun pada penyebaran geografisnya. Pandemi mengacu pada epidemi yang telah menyebar di beberapa negara atau benua, biasanya mempengaruhi sejumlah besar orang" (Nugroho, Rizal 2020)

Selain ekstensi geografis, sebagian besar penggunaan pandemi menyiratkan perpindahan penyakit atau penyebaran melalui transmisi yang dapat berpindah dari satu tempat ke tempat lain, seperti yang telah terjadi secara historis selama berabadabad (misalnya, Black Death). Contoh perpindahan penyakit meliputi penyebaran penyakit dari orang ke orang yang disebabkan oleh virus pernapasan, seperti influenza dan SARS, atau organisme enterik, seperti vibrio kolera, atau penyebaran demam berdarah yang dikaitkan dengan perluasan rentang geografis vektor, seperti nyamuk albopictusmos (Morens, D. M., Folkers, G. K. and Fauci 2007)

WHO (World Health Organization atau Badan Kesehatan Dunia) secara resmi mendeklarasikan virus corona (COVID-19) sebagai pandemi pada tanggal 9 Maret 2020. Artinya, virus corona telah menyebar secara luas di dunia. Istilah pandemi terkesan menakutkan tapi sebenarnya itu tidak ada kaitannya dengan keganasan penyakit tapi lebih pada penyebarannya yang meluas. Ingat, pada umumnya virus corona menyebabkan gejala yang ringan atau sedang, seperti demam dan batuk, dan kebanyakan bisa sembuh dalam beberapa minggu. Tapi bagi sebagian orang yang berisiko tinggi (kelompok lanjut usia dan orang dengan masalah kesehatan menahun, seperti penyakit jantung, tekanan darah tinggi, atau diabetes), virus corona dapat menyebabkan masalah kesehatan yang serius. Kebanyakan korban berasal dari kelompok berisiko itu. (Https://covid19.go.id/ 2020)

\section{Penelitian Terkait}

Dalam penyusunan penelitian ini, penulis terinspirasi dan mereferensi dari penelitian sebelumnya yang berkaitan dengan latar belakang masalah . Berikut ini penelitian terdahulu yang berhubungan dengan penelitian yaitu :

Analisis Strategi Bisnis E-commerce Perusahaan Startup Digital di Ijadfarm Surabaya. Penulis Vicky Iffah
Hasil Dalam penelitian ini adalah, strategi perusahaan startup digital online Ijadfarm berupa strategi ecommerce ini melalui integrated marketing communication yaitu situs website dan media sosial. Selain IMC sebagai marketing, strategi keunggulan bersaing Porter juga diterapkan pada bisnis di Ijadfarm. Menekan biaya operasional untuk mencapai efektifitas melalui pemanfaatan teknologi digital atau disebut dengan cost leadership, diferensiasi produk berupa sistem ramah lingkungan dari hulu hingga hilir, fokus pada diferensiasi yang mana ijadfarm hadir sebagai perusahaan startup yang memiliki pengalaman serta pengetahuan di indutsri ternak sehingga usaha yang menjadi fokus saat ini adalah usaha yang dikuasai atau ahli.(Iffah 2018)

\section{METODOLOGI PENELITIAN}

Metodologi pada penelitian ini menggunakan metodologi kualititatif dengan metode studi kasus. "metode studi kasus yaitu metode riset yang menggunakan berbagai sumber data yang bisa digunakan untuk meneliti menguraikan dan menjelaskan secara komprehensif berbagai aspek individu kelompok, suatu program, organisasi atau peristiwa secara sistematis". (Kriyantono 2006)

(Pawito 2008) mengemukakan bahwa "dalam penelitian kualitatif, kesimpulan yang dihasilkan pada umumnya tidak dimaksudkan sebagai generalisasi, tetapi sebagai gambaran interpretative tentang realitas atau gejala yang diteliti secara holistic dalam setting tertentu, disini dikandung arti bahwa temuan apapun yang di hasilkan pada dasarnya bersifat terbatas pada kasus yang di amati. Oleh karena itu, prinsip berfikir induktif lebih menonjol dalam penarikan kesimpulan dalam penelitian komunikasi kualitatif".

Metode kualitatif menurut Bogdan \& Taylor "diharapkan mampu menghasilkan suatu uraian mendalam tentang ucapan, tulisan dan tingkah laku yang dapat diamati dari suatu individu, kelompok masyarakat, organisasi tertentu dalam suatu konteks setting tertentu yang di kaji dari sudut pandang yang utuh komprehensif dan holistic"(Ruslan 2011)

(Moleong, Lexy 2002) mengemukakan bahwa "salah satu karakterisik dalam penelitian kualitatif adalah deskriptif. Dalam hal ini data yang dikumpulkan berupa kata-kata, gambar dan bukan angka-angka. Hal ini disebabkan adanya penerapan metode kualitatif. Selain itu, semua yang di kumpulkan berkemungkinan menjadi kunci terhadap apa yang sudah di teliti. Dengan demikian laporan penelitian akan berisi kutipan-kutipan data untuk memberi gambaran penyajian laporan tersebut”.

Teknik pengumpulan data dalam penelitian ini menggunakan observasi, dokumentasi. 
Observasi berasal dari kata "observantion" yang berarti pengamatan. Metode observasi dilakukan dengan cara mengamati perilaku, kejadian atau kegiatan orang atau sekelompok orang yang diteliti. kemudian mencatat hasil pengamatan tersebut untuk mengetahui apa yang sebenarnya berupa, daftar cek, tabel sosiometri, catatan lapangan, jurnal harian, alat perekam elektronik dan format lainnya.(Djaelani 2013)

Dalam penelitian penulis menggunakan observasi dengan mengamati mengenai Startegi Bisnis Startup Social Enterprise Wahyoo dalam menghadapi situasi pandemi COVID-19

Dokumentasi (Ningrum, 2015) dalam Hamidi Metode dokumentasi adalah "informasi yang berasal dari catatan penting baik dari lembaga atau organisasi maupun dari perorangan". Dokumentasi adalah "ditujukan untuk memperoleh data langsung dari tempat penelitian meliputi: buku-buku yang rilevan, peraturan-peraturan, laporan kegiatan, foto-foto, film dokumenter data yang rilevan penelitian."(Riduawan 2006)

\section{HASIL DAN PEMBAHASAN}

Perusahaan rintisan bernama Wahyoo berdiri pada bulan Mei 2017. Wahyoo adalah platform jasa bagi pengusaha warung makan yang menyediakan berbagai layanan, seperti penjualan pulsa, edukasi usaha katering, program asistensi bisnis, hingga standardisasi kebersihan tempat usaha. (Anggraeni 2018)

WAHYOO adalah "perusahaan teknologi yang memberikan nilai tambah dan bermanfaat bagi warung-warung di Indonesia" Misi wahyoo adalah membantu Masyu dan Mbakyu menjadi lebih baik (Https://wahyoo.com/ 2017)

Seiring dengan pengembangan Wahyoo Peter menemukan beberapa masalah yang dihadapi pengusaha warteg dan warung makan sederhana lain, seperti manajemen waktu yang buruk dan kesadaran akan kebersihan yang rendah. Catatan keuangan dari warteg tersebut juga kurang rapi. Akibatnya, meski laku, warteg dan warung nasi sederhana lain kerap dilecehkan sebagai tempat makan orang rendahan. Jauh dari kata keren dan tak cocok untuk generasi milenial yang mengedepankan gaya hidup mewah.

Mitra warteg yang bergabung dengan Wahyoo mendapatkan akses pada portal online untuk menjual berbagai produk, seperti pulsa. Layanan Wahyoo berkembang menjadi penyedia barang, permodalan, hingga akses pada bisnis baru. Saat ini, sudah ada 2.500 warung yang tergabung dalam jaringan Wahyoo. Peter menargetkan tahun depan sebanyak 15 ribu warung bisa bergabung. Namun, untuk bergabung di dalam Wahyoo, salah satu persyaratan yang harus dipenuhi yaitu mereka harus menempati lahan legal dan memiliki produktivitas baik. Bagi Peter, peluang bisnis di warteg sangat besar mengingat di Jakarta ada 35 ribu warteg dan warung makan lain, dengan omzet minimal 100 porsi per hari.(Anggraeni 2018)

Wahyoo merupakan salah satu perusahaan rintisan (startup) yang turut mengalami badai krisis Pandemi Covid-19. Diakui Daniel Cahyadi, C--Founder dan COO Wahyoo, selama PSBB (Pembatasan Sosial Berskala Besar), pendapatan Wahyoo menurun $50 \%$. SUMBER (Wulandari 2020)

Berikut ini strategi bisnis yang di laksanakan wahyoo

\section{1. \#RANTANG hati (Pendistribusian 100.000 Nasi Bungkus)}

Dampak pandemi Covid-19 tak hanya memaksa kita \#DiRumahAja, tapi juga membuat banyak orang kehilangan pekerjaan, bahkan tak sedikit dari mereka yang harus gulung tikar. Hal ini melatarbelakangi Wahyoo dengan gerakan \#RantangHati-nya bekerja sama dengan Konser Musik \#DiRumahAja untuk membantu membagikan makanan gratis selama masa physical distancing pandemi virus corona.

Founder dan CEO Wahyoo Group, Peter Shearer menyatakan, "Penerapan physical distancing yang berimbas pada imbauan kerja dari rumah, membuat warung makan di Jadetabek sepi pengunjung. Ironisnya, sebenarnya banyak orang yang tidak sanggup membeli makanan di warung. Rata-rata adalah pekerja informal dengan kondisi pekerjaan yang tak menghasilkan saat ini. Kami Wahyoo mencoba menjembatani agar dapur warung ini tetap ngebul dengan cara mereka memasak makanan bagi orang yang membutuhkan," (Agmasari 2020)

Terim kasih \#OrangBaik, sebanyak Rp 450.000.000 berhasil disalurkan kepada 961 kepala keluarga (KK) yang tersebar di Jakarta dan Tangerang selama 14 hari. Setiap KK terdampak mendapat 2 porsi makanan (nasi, sayur, dan lauk-pauk) selama 14 hari. Tak hanya memastikan setiap orang bisa makan layak dan sehat, \#RantangHati juga membantu pemilik warung makan konvensional agar bisa terus bekerja dan memenuhi kebutuhan sehari-hari. Makanan yang dibagikan dalam kampanye ini dimasak oleh warung makan yang merupakan mitra Wahyoo. Pembagian makanan berjalan sejak 30 Maret dan berakhir $5 \mathrm{Mei}$ $2020 \quad$ (Https://wahyoo.com/

2020)

Dalam kegiatan tersebut, Wahyoo bersama ketua RT di wilayah Jakarta dan Tangerang mendata wargawarga yang membutuhkan bantuan. Setelah itu, makanan yang telah disiapkan dikirim ke rumah ketua RT dan dibagikan langsung ke rumah-rumah warga.

Untuk memodali warung makan memasak makanan, Wahyoo butuh donatur. Untuk itu dibuka donasi terbuka melalui platform donasi online KitaBisa. 
Taget Wahyoo adalah mengumpulkan Rp 350 juta. Uang tersebut akan dibagikan pada warung makan untuk memasak bagi 700 orang yang membutuhkan selama dua minggu. Dalam sehari orang tersebut akan menerika makanan dua kali sehari. "Kami bujet Rp 15.000 per orang sekali makan, jadi sehari Rp 30.000 untuk pengeluaran makannya," jelas Peter. (Agmasari 2020)

Dalam gerakan \#RantangHati, warung makan yang selesai memasak akan dibantu pengemudi Gojek dan relawan Aksi Cepat Tanggap (ACT) untuk menyalurkan ke orang yang membutuhkan. Jadi ACT yang akan melakukan penyaringan bagi penerima makanan tersebut. "Bisa juga kirim pesan ke medsos Wahyoo siapa orang sekitar atau mungkin dia sendiri yang butuh makanan. Akan kami buatkan databasenya," jelas Peter. Sejauh ini, Peter menyebutkan mitra warung makan sangat senang akan inisiasi gerakan \#RantangHati, karena dapat membantu mendongkrak pendapatan mereka yang berkurang. Untuk gerakan \#RantangHati, Wahyoo dibantu oleh berbagai pihak termasuk influencer Edho Zell, ACT, Gojek, dan presenter Najwa Shihab yang membuka donasi lewat Konser Musik \#DiRumahAja(Agmasari

2020)

Terima kasih. Tak hanya terucap dari warga yang menerima bantuan, tapi juga dari pemilik warung, ketua RT, bahkan para pengemudi transportasi online yang bertugas mengirimkan makanan. Bukan soal berapa yang bisa diberikan, tapi kebaikan kecil yang teman-teman berikan membawa senyum kepada mereka yang terdampak. Terima kasih \#OrangBaik, makanan ini jadi semangat kita untuk tetap \#DiRumahAja. (Https://wahyoo.com/ 2020)

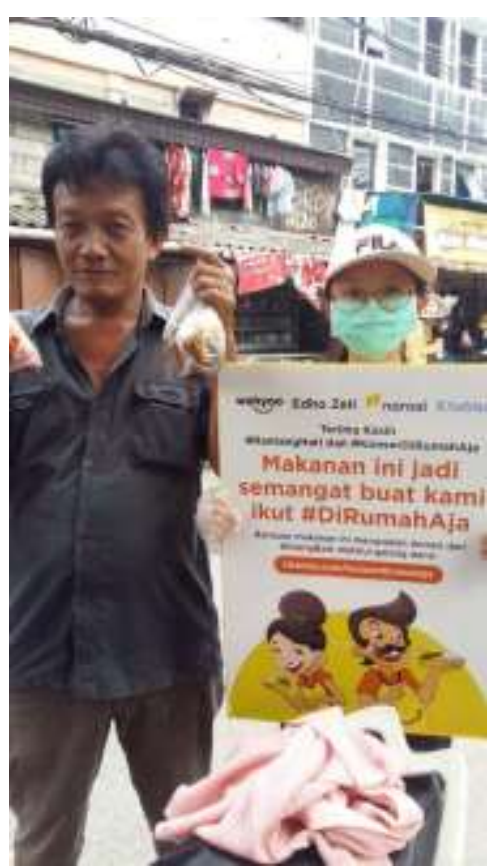

Sumber : wahyoo.com

Gambar 1.

Rantang hati

\section{Warteg New Normal Wahyoo.}

Warteg New normal ala wahyoo merupakam warteg percontohan yang telah menerapkan standarisasi protokol kesehatan untuk mitra warteg, pelayan diwajibkan memakai masker, sarung tangan, dan face shield saat melayani konsumen. Konsumen juga hanya boleh memesan di sudut dengan plastik pembatas yang sudah tersedia. Cara pembayarannya bisa dilakukan dengan nontunai menggunakan Gopay atau memasukkan uang ke kotak yang tersedia. Pada warteg tersedia layanan untuk makan di tempat, namun konsumen diharapkan membeli makan untuk dibawa pulang. Hal ini dikarenakan kapasitas tempat duduk terbatas, hal itu juga bisa menghindari kontak dengan pembeli yang lainya.

Sebanyak 100 mitra warung makan telah disiapkan sebagai warteg new normal untuk menjadi percontohan bagi warung makan lainnya di seluruh Indonesia. Peter Shearer, Founder dan CEO Wahyoo Group mengatakan kesehatan Masyu dan Mbakyu pemilik warung makan serta pelanggan mereka adalah prioritas utama Wahyoo.

"Agar warung makan tetap beroperasi dengan aman dan nyaman, kami berharap protokol warteg new normal ini bisa diimplementasi di banyak warung makan tradisional lainnya,"

Menanggapi era new normal yang dicanangkan pemerintah Indonesia dalam upaya pencegahan penyebaran Covid-19 baru-baru ini, Masyu dan Mbakyu mitra warung makan Wahyoo diberikan standar operasional atau protokol kesehatan dalam pelaksanaan usaha sehari-hari. (Hironimus, 2020) 
Protokol Kesehatan warteg new normal yang disampaikan di antaranya ialah:

1. Wajib memakai masker bagi pelanggan

2. Cuci tangan dengan sabun saat masuk dan keluar warung

3. Bergantian saat masuk, mengantre, dan keluar warung

4. Masyu \& Mbakyu dilengkapi dengan masker, face shield, dan sarung tangan selama melayani pelanggan

5. Kebersihan dan higienitas makanan menjadi prioritas kami

6. Atur jarak dengan pengunjung lain saat makan di tempat

7. Masker jangan dilepas kecuali saat makan dan minum saja

8. Lebih baik makanan dibungkus atau pesan lewat GoFood

9. Pembayaran via GoPay atau masukkan uang pas ke dalam kotak yang tersedia

10. Meja dan kursi dibersihkan dengan disinfektan secara berkala

Dalam penerapan protocol kesehatan warteg new nirmal menapatkan tanggapan baik dari mitra wahyo salah satunya adalah Suti, pemilik Warteg Ellya yang berlokasi di Jl. Madrasah No. 7, Jakarta Selatan.

Suti menyatakan, "Para pembeli yang datang merasa senang dengan adanya protokol kesehatan warteg new normal ini, di antaranya malah ada yang foto-foto dan dibagikan di sosial media. Mereka juga merasa aman dan nyaman, ngga perlu desak-desakan selama makan, " selain itu Suti merasa senang karena dengan diterapkan protokol kesehatan warteg new normal yang diberikan Wahyoo membuat pelanggan tetap mau makan di warung.

Setelah percobaan di Warteg Ellya, Wahyoo mempersiapkan 100 warung makan mitra Wahyoo lainnya yang tersebar di Jakarta, Depok, Tangerang dan Bekasi untuk mengikuti protokol warteg new normal

Langkah ini dilakukan agar upaya pencegahan Covid19 yang dicanangkan pemerintah dapat berlaku dengan baik terutama bagi para pengusaha warung makan dan para konsumennya.(Hironimus, 2020)

Lebih lanjut Daniel Cahyadi, C--Founder dan COO Wahyoo, menyatakan "Biaya untuk produksi warteg percontohan ini memang cukup besar. Oleh karena itu, kami akan mengundang brand untuk berpartisipasi, karena sekat-sekat tersebut apat digunakan branding oleh para pemilik merek". (Wulandari 2020)

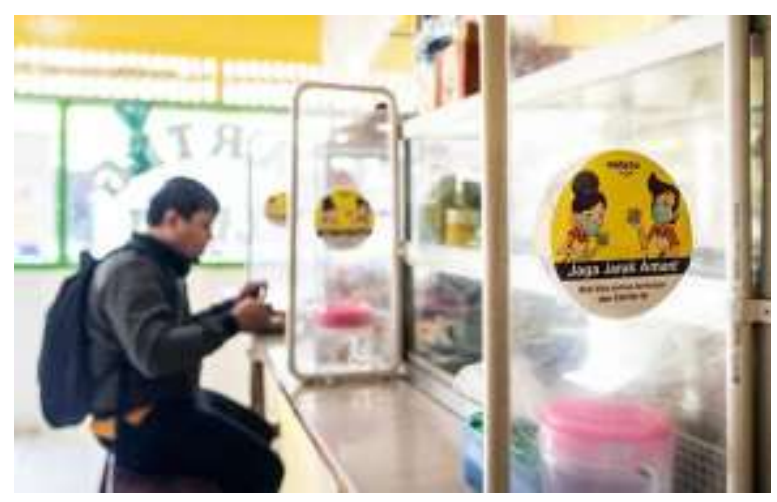

Sumber : dok. https://mix.co.id/

Gambar 1

Warteg new normal

\section{Membuka Unit Bisnis Baru,}

Langkah strategi bisnis yang dilaksana Wahyoo Group, pada saat pandemi yang lainnya yaitu dengan meluncurkan Langganan.co.id. Yakni sebuah ecommerce groceries yang menargetkan masyarakat residential, seperti di area perumahan atau apartemen dihadirkan ini untuk menjawab perubahan perilaku konsumen selama Pandemi.

Founder \& CEO Wahyoo Peter Shearer menyatakan platform barunya tersebut menargetkan pasar yang berbeda dengan Wahyoo. Hanya saja Langganan.co.id hadir dan beroperasi menggunakan infrastruktur milik Wahyoo seperti inventori, gudang, dan logistik yang biasanya digunakan untuk melayani pemilik warung makan." Lebih lanjut Peter menyatakan bahwa, "Dengan adanya Langganan.co.id ini kami ingin menekan ongkos distribusi dan juga memberikan volume lebih besar kepada supplier kami,"

Langganan.co.id yang baru mulai beroperasi Juni 2020 masih terus berusaha disempurnakan. Dengan fitur jual beli yang ada, hingga saat ini mereka sudah menjangkau beberapa perumahan atau apartemen, seperti Green Lake City, Alam Sutera, Cipondih, Taman Royal, Banjar Wijaya, Modernland, Gading Serpong, Karawaci, Metro Permata, Ciledug, Puri, hingga PIK.(Ryza 2020)

Lebih lanjut Daniel Cahyadi, C--Founder dan COO Wahyoo, menyatakan." Platform langganan.co.id ini masih terbatas melayani daerah Jakarta Barat dan Tangerang. Ke depan, layanan ini akan kami perluas ke kota lain, misalnya ke daerah Timur," tutup Daniel, yang menyebutkan bahwa pertumbuhan Langganan.co.id sejak April hingga sekarang mencapai dua kali lipat per bulannya. (Wulandari 2020)

\section{KESIMPULAN}

Pada masa Pandemic covid-19 Pemerintah mengeluarkan beberapa kebijakan sebagai solusi 
untuk menekan angka penyebaran virus yang terjadi dengan cepat yaitu dengan menghentikan penularan virus melalui mengurangi interaksi atau kontak langsung antar masyarakat. Tiga istilah yang digunakan yaitu karantina wilayah, Pembatasan Sosial Berskala Besar (PSBB) dan lockdown.

Startup Social Enterprise Wahyoo Berdiri pada bulan Mei 2017 Wahyoo perusahaan rintisan yang mengelola warteg. Dalam upaya mempertahankan usaha bisnis di Masa Pandemic covid-19 wahyoo melaksanakan langkah startegis bisnis yaitu, :

1. Pertumbuhan, wahyoo memperluas produk yang ditawarkan bukan saja pada pengelolaan warteg tetapi juga bagaimana memperoleh produk yang akan di gunakan dalam usaha bisnisnya Wahyoo merupakan platform jasa bagi pengusaha warung makan yang menyediakan berbagai layanan, seperti penjualan pulsa, edukasi usaha katering, program asistensi bisnis, hingga standardisasi kebersihan tempat usaha.

2. Stabilitas, Dalam masa pandemic covid, pengelola warteg tetap melayani pembeli dengan menerapkan protokol kesehatan yaitu warteg new normal, sehingga konsumen dapat membeli produk.

3. Pembaharuan, Wahyoo membuka unit baru yaitu dengan langgan go id tujuanya untuk menyuplai kebutuhan warung. Platform ini juga ditujukan pada kelompok konsumen pembeli produk fast-moving consumer goods (FMCG). Wilayah operasi masih terbatas di kawasan Tangerang dan Jakarta Barat. Langganan co.id layanan baru dari Wahyoo ini mengikuti kebutuhan delivery produk FMCG yang permintaannya berkembang di tengah pandemi COVID-19.

Dengan strategi bisnis yang dilaksanakan oleh Startup social entrepraise Wahyo dapat mempertahankan usaha UMKM yaitu Warteg dalam menghagapi pandemic covid -19

\section{REFERENSI}

Afriyadi, Achmad Dwi. 2020. "Omzet Pengusaha Warteg Anjlok 50\% Dihantam Corona." https://finance.detik.com/. https://finance.detik.com/berita-ekonomibisnis/d-4955563/omzet-pengusaha-warteganjlok-50-dihantam-corona (November 7, 2020).

Agmasari, Silvita. 2020. "Rantang Hati, Gerakan Bantu Warung Makan Masak Makanan Gratis

\author{
Di Tengah Pandemi Covid-19." \\ https://travel.kompas.com/. \\ https://ravel.kompas.com/read/2020/03/29/14 \\ 5226127/rantang-hati-gerakan-bantu-warung- \\ makan-masak-makanan-gratis-di- \\ tengah?page $=1($ November 16,2020$)$.
}

Anggraeni, Kartika. 2018. "Startup Pilihan Tempo 2018: Wahyoo, Polesan Warteg Gaya Milenial.” https://bisnis.tempo.co/. https://bisnis.tempo.co/read/1153471/startuppilihan-tempo-2018-wahyoo-polesan-warteggaya-milenial/full\&view=ok (November 16, 2020).

Djaelani, Auinu Rofiq. 2013. “Teknik Penggumpulan Data Dalam Penelitian Kualitatatif.” XX.

Hironimus, and TIS. 2020. "Terapkan Protokol Kesehatan, Begini Standar Operasional Dan Wujud Warteg New Normal Mitra Wahyoo." https://wartakota.tribunnews.com/. https://wartakota.tribunnews.com/2020/06/17/t erapkan-protokol-kesehatan-begini-standaroperasional-dan-wujud-warteg-new-normalmitra-wahyoo?page $=3$ (November 16, 2020).

Https://covid19.go.id/. 2020. "Apa Yang Dimaksud Dengan Pandemi?” htps://covid19.go.id/. https://covid19.go.id/tanya-jawab? search=Apa yang dimaksud dengan pandemi? (November 16, 2020).

https://databoks.katadata.co.id/. 2019. "Berapa Jumlah Startup Di Indonesia." https://databoks.katadata.co.id/datapublish. https://databoks.katadata.co.id/datapublish/201 9/01/14/berapa-jumlah-startup-di-indonesia (November 7, 2020).

https://mastahbisnis.com/. 2020. "Strategi Bisnis." https://mastahbisnis.com/. https://mastahbisnis.com/strategi-bisnis/ (November 7, 2020).

Https://pendidikan.co.id. 2020. "PengertianStartup.” https://pendidikan.co.id/pengertianstartup/ (November 7, 2020).

Https://wahyoo.com/. 2017. "Misi." https://wahyoo.com/. https://wahyoo.com/ (November 16, 2020).

https://wahyoo.com/.2020. "Lawan Covid 19 Bersama Rantanghati x Konser Musik Dirumahaja.”. https://wahyoo.com/blog/lawan-covid-19-bersamarantanghati-x-konser-musik-dirumahaja/ (November 16, 2020).

Https://www.dbs.com/. 2018. "Mengapa Millennials Perlu Menggiatkan Social Enterprise, Bukan Sekadar Social Cause." https://www.dbs.com/. 
https://www.dbs.com/spark/index/id_id/site/pil lars/2018-mengapa-millennials-perlumenggiatkan-social-enterprise,-bukan-sekadarsocial-cause.html\#: :text=Social enterprise atau wirausaha sosial adalah sebuah organisasi,bagi setiap elemen yang terlibat di dalam usahanya. (November 16, 2020).

Https://www.who.int/. 2020. "Novel-Coronavirus." https://www.who.int/indonesia/. https://www.who.int/indonesia/news/novelcoronavirus/qa-for-public (July 6, 2020).

Iffah, Vicky. 2018. “Analisis Strategi Bisnis ECommerce Perusahaan Startup Digital Di Ijadfarm Surabaya." UNIVERSITAS ISLAM NEGERI WALISONGO. http://eprints.walisongo.ac.id/8978/1/Vicky Iffah__1405026093.pdf.

Kriyantono, Rachmat. 2006. Teknik Praktis Riset Komunikasi. jakarta: Jakarta: Kencana,.

Lestarini, Ade Hapsari. 2020. "Warteg Masuk Jajaran UMKM." https://economy.okezone.com/. https://economy.okezone.com/read/2010/12/02 /320/399514/warteg-masuk-jajaran-umkm (November 7, 2020).

Liputan6.com. 2019. "Pengertian Startup Adalah, Sejarah Singkat Dan Karakteristiknya." https://www.liputan6.com/. https://www.liputan6.com/tekno/read/3867489 /pengertian-startup-adalah-sejarah-singkatdan-karakteristiknya (November 16, 2020).

Marikxon. 2020. “Apa Itu Startup: Pengertian, Dan Perkembangan Bisnis Startup Di Indonesia." https://www.maxmanroe.com/. https://www.maxmanroe.com/apa-itustartup.html (November 16, 2020).

Moleong, Lexy, J. 2002. Moleong, Lexy, J, c Metode Penelitian Kualitatif, PT Remaja Rosda Karya, Bandung. Bandung: Remaja Rosda Karya,.

Morens, D. M., Folkers, G. K. and Fauci, A. S. 2007. "What Is a Pandemic?" The Journal of Infectious Diseases, : 1018-1021.

Nugroho, Rizal, Setyo. 2020. “Apa Itu Pandemi Global Seperti Yang Dinyatakan WHO Pada Covid-19?" kompas.com. https://www.kompas.com/tren/read/2020/03/1 2/060100465/apa-itu-pandemi-global-sepertiyang-dinyatakan-who-pada-covid-19 (July 26, 2020).

Pawito. 2008. Pawito, 2008, Penelitian Komunikasi Kualitatif, LKIS, Pelangi, Aksara, Yogyakarta. Yogyakarta: LKIS, pelangi, Aksara,.
Prayoga, Fadel. 2020. "5 Jenis Umkm Yang Paling Terdampak Covid 19."

https://economy.okezone.com/. https://economy.okezone.com/read/2020/07/15 /320/2246713/5-jenis-umkm-yang-palingterdampak-covid-19 (November 7, 2020).

Riduawan. 2006. Metode \& Teknik Penyusunan Tesis. Bandung: Alfabeta.

Rizka, Ikmal. 2019. "Perkembangan Bisnis Startup Di Indonesia 2019." https://rintisanstartup.com/. https://rintisanstartup.com/perkembanganbisnis-startup-di-indonesia-2019/ (November 7, 2020).

Ruslan, Rosady. 2011. Ruslan, Rosady, 2011, Metodologi Penelitian Public Relations Dan Komunikasi Cetakan Ke 5 Rajawali Pers Jakarta. cetakan ke. jakarta: rajawali pers Jakarta.

Ryza, Prayogo. 2020. "Wahyoo Luncurkan Langganan.Co.Id, Platform Online Untuk Belanja Sembako." https://dailysocial.id/. https://dailysocial.id/post/wahyoo-luncurkanlangganan-co-id-platform-online-untukbelanja-sembako (November 16, 2020).

Setiawan, Wawan. 2018. "Wahyoo, Aplikasi Digital Untuk Warteg.” https://mix.co.id/marcomm/ https://mix.co.id/marcomm/brandinsight/marketing-strategy/wahyoo-aplikasidigital-untuk-warteg/\%0A (November 7, 2020).

Susanto, AB. 2005. Manajemen Komprehensif Strategik. Jakarta: Erlangga.

Wulandari, Dwi. 2020. “Tiga Langkah Strategis Wahyoo Hadapi Pandemi." https://mix.co.id/. https://mix.co.id/marcomm/brandinsight/marketing-strategy/tiga-langkahstrategis-wahyoo-hadapi-pandemi/\%0A (November 7, 2020).

\section{PROFIL PENULIS}

Siti Qona'ah S.Sos. MM lahir di Bandung, 26 Maret 1973 adalah dosen di Universitas Bina Sarana Informatika Fakultas Ilmu Komunikasi dan Bahasa Program Studi Hubungan Masyarakat sejak bulan Mei 2007. Pendidikan S1 yang ditempuh di Fakultas komunikasi Jurusan Public Relations di Institut Ilmu Sosial dan Politik (IISIP) selesai pada tahun 1997. beliau sudah menyelesaikan pendidikan Strata dua (S2) Magister Manajemen pada Universitas BSI Bandung pada tahun 2012 dan saat ini sedang menyelesaikan Program Pasca Sarjana (S2) Magister Ilmu Komunikasi di Universitas Sahid Jakarta. 